\title{
Emotional Freedom Technique to Prevent Preeclampsia: Literature Review
}

\author{
Anila Iliani ${ }^{1}$, Sismeri Dona ${ }^{2}$ and Dwi Rahmawati ${ }^{3}$ \\ \{sismeridonas2keb06@gmail.com $\left.{ }^{2}\right\}$ \\ Midwifery Study Program, Health Faculty, Universitas Sari Mulia, Indonesia ${ }^{123}$
}

\begin{abstract}
Emotional Freedom Technique (EFT) is a technique of self-empowerment and alignment of the body's energy system to overcome physical and psychological problems, in which pregnancy changes both physically and psychologically. This literature study aims to examine articles related to Emotional Freedom Technique for Preventing Preeclampsia. This study used a literature study approach using several sources selected based on predetermined criteria, by the researcher. The EFT and SEFT methods are effective in reducing cortisol levels, where the role of cortisol is very influential in reducing blood pressure, blood circulation, and heart rate. Stress as a trigger response to increase cortisol in the body, this also occurs in the blood pressure of preeclamptic mothers. EFT and SEFT have an effect on decreasing cortisol levels so that blood pressure decreases which occurs in mothers with preeclampsia.
\end{abstract}

Keywords: Emotional Freedom Technique; Hypertension; Preeclampsia

\section{Introduction}

Preeclampsia is a hypertensive condition that is found at gestational age above 20 weeks until delivery where blood pressure is $\geq 140 / 90 \mathrm{~mm} \mathrm{Hg}$ on two measurements with a time interval of 4 hours, or blood pressure $\geq 160 / 110 \mathrm{~mm} \mathrm{Hg}$ [1]. 94\% of maternal mortality occurs in developing countries, in 2017 the maternal mortality ratio is around 295 per 100,000 live births in developing countries. From the problem of high maternal mortality, these countries through the World Health Organization are trying to reduce the mortality rate, and every day around 830 mothers die during pregnancy and childbirth [2].

The incidence of preeclampsia worldwide is between $3 \%$ and $14 \%$ of all pregnancies. There has been no evidence to suggest a change to this number in at least the last ten years. Preeclampsia is a major cause of maternal morbidity and mortality in developing areas, and causes an increase of up to 5 times in perinatal mortality. In the world, 50,000-70,000 women die each year due to preeclampsia and eclampsia. WHO (World Health Organization) estimates that preeclampsia cases are seven times higher in developing countries than in developed countries? The low prevalence in developed countries ranges from $1.3 \%-6 \%$ compared to that in developing countries, namely $1.8 \%-18 \%$ indicating that there is a side of preeclampsia that we can prevent in health service management [3].

The Maternal Mortality Rate in South Kalimantan Province in 2018 was recorded at 79 per 100,000 KH and in 2019 there were 63 deaths per 100,000 KH. Causes of Maternal Mortality in South Kalimantan Province due to circulation (28.6\%), hypertension (28.6\%), 
infection $(6.3 \%)$, circulatory system disorders (1.6\%), metabolic disorders (8\%), others $(27 \%)$ [4].

Preeclampsia is the occurrence of hypertension accompanied by proteinuria due to pregnancy, after 20 weeks of gestation or immediately after delivery [5]. Symptoms of preeclampsia include excess body weight, edema, swelling of the face, hands and feet, hypertension, proteinuria, achotoma, visual disturbances, epigastric pain, severe headaches that can cause anxiety so that it can be treated with the Emotional Freedom Technique method. Emotional Freedom Technique is a technique of self-empowerment and alignment of the body's energy system to deal with physical problems (such as prolonged headaches, back pain, allergies, asthma, heart arrythmia, fatigue, and smoking) and emotional (trauma, depression, phobia, stress, difficulty). sleeping, boredom, lazy, nervous, anxious, insecure, etc. EFT is a combination of spirituality (through faith, prayer and sincerity) and energy psychology.

In a study conducted by Chuka Mike, 2017 There is a strong relationship between emotional reactivity and the incidence of increased blood pressure [6]. From this data, the authors are interested in conducting a Literature Review on Emotional Freedom Technique to prevent preeclampsia.

\section{Method}

The research method used a literature review. The Literature review method is a form of research carried out through tracing by reading various sources both books, journals, and other publications related to research topics to answer existing issues or problems [7].

\section{Result and Discussion}

The results of the literature review can be concluded that the EFT and SEFT methods are very useful in improving health, where the EFT and SEFT methods can provide a relaxing effect to reduce cortisol levels, reduce anxiety and emotional levels (Table 1).

Table 1. Results of literature review

\begin{tabular}{|c|c|c|c|c|}
\hline $\begin{array}{c}\text { Author } \\
\text { (years) }\end{array}$ & Source & Objective & Method & Output \\
\hline $\begin{array}{c}\text { Donna } \\
\text { Bact, et al } \\
2019\end{array}$ & Pub Med & $\begin{array}{l}\text { The first focuses on } \\
\text { information about the } \\
\text { physiological effects } \\
\text { of EFT is limited. } \\
\text { The second aim was to } \\
\text { measure psychological } \\
\text { symptoms. }\end{array}$ & Quantitative & $\begin{array}{l}\text { The findings with EFT were a } \\
\text { decrease in pain and anxiety } \\
\text { levels, a decrease in post- } \\
\text { traumatic stress disorder, pain } \\
\text { and an increase in happiness, } \\
\text { an increase in the } \\
\text { immunoglobulin A system, an } \\
\text { improvement in the circulatory } \\
\text { system, a decrease in cortisol } \\
\text { levels } 37 \% \text {, a decrease in } \\
\text { systolic blood pressure } 6 \% \text { and } \\
8 \% \text { diastole. thus, providing }\end{array}$ \\
\hline
\end{tabular}




\begin{tabular}{|c|c|c|c|c|}
\hline & & & & $\begin{array}{l}\text { positive health effects and } \\
\text { increased mental well-being. }\end{array}$ \\
\hline $\begin{array}{l}\text { Mardjan, } \\
\text { et al } 2018\end{array}$ & DOAJ & $\begin{array}{l}\text { This study aims to } \\
\text { assess } \\
\text { effectiveness of EFT } \\
\text { in reducing anxiety } \\
\text { facing childbirth. }\end{array}$ & Quantitative & $\begin{array}{l}\text { 1. EFT can reduce } 57 \% \\
\text { anxiety in mothers about } \\
\text { readiness to face childbirth } \\
\text { 2. The EFT method can } \\
\text { significantly reduce } 43 \% \\
\text { of blood cortisol levels } \\
\text { which indirectly affects the } \\
\text { readiness of the mother to } \\
\text { face childbirth. }\end{array}$ \\
\hline $\begin{array}{l}\text { Yuniarti, } \\
\text { et al } 2016\end{array}$ & $\begin{array}{l}\text { Google } \\
\text { Scholar }\end{array}$ & $\begin{array}{l}\text { This study aims to } \\
\text { determine the effect of } \\
\text { the SEFT method in } \\
\text { reducing stress and } \\
\text { depression in } \\
\text { primigravida mothers } \\
\text { in facing childbirth. }\end{array}$ & Quantitative & $\begin{array}{l}\text { 1. The SEFT method is } \\
\text { effective in reducing } \\
\text { cortisol levels in } \\
\text { primigravida mothers } \\
\text { 2. With the SEFT method, } \\
\text { there was a decrease in the } \\
\text { levels of immunoglobulin } \\
\text { E in primigravida mothers }\end{array}$ \\
\hline $\begin{array}{c}\text { Roee } \\
\text { Admon, } \\
\text { et al 2020 }\end{array}$ & $\begin{array}{l}\text { Google } \\
\text { Scholar }\end{array}$ & $\begin{array}{l}\text { The first aim of the } \\
\text { current study was to } \\
\text { induce acute stress } \\
\text { effectively for a } \\
\text { relatively prolonged } \\
\text { time period among } \\
\text { healthy females while } \\
\text { capturing individual } \\
\text { endocrine and } \\
\text { affective response } \\
\text { patterns. }\end{array}$ & Quantitative & $\begin{array}{l}\text { There is a significant effect of } \\
\text { time driven by stress due to } \\
\text { increased cortisol and negative } \\
\text { effects particularly cortisol } \\
\text { levels and the effect is still } \\
\text { increasing } 65 \text { and } 100 \text { minutes } \\
\text { after stress onset, respectively } \\
\text { reflecting a relatively } \\
\text { prolonged induction of acute } \\
\text { stress. }\end{array}$ \\
\hline $\begin{array}{l}\text { Lutfatul } \\
\text { Latifah, et } \\
\text { al } 2019\end{array}$ & $\begin{array}{l}\text { Google } \\
\text { Scholar }\end{array}$ & $\begin{array}{l}\text { The aim of this study } \\
\text { is to define the } \\
\text { influence of tapping } \\
\text { therapy to anxious } \\
\text { reduction and labor } \\
\text { pain during latent } \\
\text { phase on nullipara } \\
\text { mother }\end{array}$ & Quantitative & $\begin{array}{l}\text { The results found that } 30 \\
\text { minutes of EFT therapy can } \\
\text { reduce pain by } 40 \% \text { and can } \\
\text { reduce anxiety by } 60 \% \text {. }\end{array}$ \\
\hline $\begin{array}{l}\text { Aryanti, } \\
\text { et al } 2019\end{array}$ & $\begin{array}{l}\text { Google } \\
\text { Scholar }\end{array}$ & $\begin{array}{l}\text { This study aims to } \\
\text { identify the effect of } \\
\text { EFT therapy on } \\
\text { lowering blood } \\
\text { pressure in } \\
\text { hypertensive elderly. }\end{array}$ & Quantitative & $\begin{array}{l}\text { The results showed a decrease } \\
\text { in systolic blood pressure but at } \\
\text { diastolic blood pressure there } \\
\text { was no significant decrease in } \\
\text { blood pressure in the EFT } \\
\text { intervention group. }\end{array}$ \\
\hline $\begin{array}{l}\text { Barkah } \\
\text { Hidayatull } \\
\text { oh, et al }\end{array}$ & $\begin{array}{l}\text { Google } \\
\text { scholar }\end{array}$ & $\begin{array}{l}\text { This study aims to } \\
\text { determine the } \\
\text { effectiveness of SEFT }\end{array}$ & Quantitative & $\begin{array}{l}\text { In the group with } 1 \text { round of } \\
\text { SEFT there was a decrease in } \\
\text { systolic blood pressure of } 14.1\end{array}$ \\
\hline
\end{tabular}




\begin{tabular}{|c|c|c|c|c|}
\hline 2018 & & $\begin{array}{l}\text { therapy on blood } \\
\text { pressure } \\
\text { hypertensive patients }\end{array}$ & & $\begin{array}{l}\mathrm{mmHg} \text { and diastolic of } 4.8 \\
\mathrm{mmHg} \text {, while in the } 3 \text { rounds } \\
\text { of SEFT the decrease in cytolic } \\
12.8 \mathrm{mmHg} \text { and diastolic } 1.3 \\
\mathrm{mmHg} \text { this difference appeared } \\
\text { to decrease in the group } 3 \text { times } \\
\text { the SEFT intervention cycle. } \\
\text { due to a decrease in the } \\
\text { concentration of participants } \\
\text { and the response to rejection of } \\
\text { the therapist's instructions so } \\
\text { that it affects the success rate of } \\
\text { therapy. }\end{array}$ \\
\hline $\begin{array}{c}\text { Ros } \\
\text { Endah, } \\
\text { et al } 2020\end{array}$ & $\begin{array}{l}\text { Google } \\
\text { scholar }\end{array}$ & $\begin{array}{l}\text { This study aims to } \\
\text { increase } \\
\text { knowledge of the } \\
\text { elderly about } \\
\text { hypertension and } \\
\text { increase awareness to } \\
\begin{array}{l}\text { control blood pressure } \\
\text { and lower blood } \\
\text { pressure with SEFT } \\
\text { therapy. }\end{array}\end{array}$ & Quantitative & $\begin{array}{l}\text { By providing health education, } \\
\text { it can increase knowledge and } \\
\text { awareness in controlling blood } \\
\text { pressure, the SEFT method is } \\
\text { effective in reducing blood } \\
\text { pressure in elderly people with } \\
\text { hypertension. }\end{array}$ \\
\hline $\begin{array}{c}\text { Anggita, et } \\
\text { al } \\
2020\end{array}$ & $\begin{array}{l}\text { Google } \\
\text { scholar }\end{array}$ & $\begin{array}{l}\text { The study aimed to } \\
\text { examine the } \\
\text { effectiveness of giving } \\
\text { SEFT to decrease } \\
\text { blood pressure in the } \\
\text { class of pregnant } \\
\text { women with } \\
\text { hypertension }\end{array}$ & Quantitative & $\begin{array}{l}\text { There was a decrease in blood } \\
\text { pressure in the intervention } \\
\text { group. After the SEFT } \\
\text { intervention once a day with a } \\
\text { duration of } 30 \text { minutes for } 14 \\
\text { days, there was a decrease in } \\
\text { systolic blood pressure of } 12 \\
\mathrm{mmHg} \text { and diastolic } 12.8 \\
\mathrm{mmHg} \text {. }\end{array}$ \\
\hline $\begin{array}{l}\text { Sholihul } \\
\text { Huda, et al } \\
2018\end{array}$ & $\begin{array}{l}\text { Google } \\
\text { scholar }\end{array}$ & $\begin{array}{l}\text { This study aims to } \\
\text { determine the effect of } \\
\text { SEFT therapy on } \\
\text { reducing blood } \\
\text { pressure in patients } \\
\text { with hypertension. }\end{array}$ & Quantitative & $\begin{array}{l}\text { With SEFT intervention, there } \\
\text { was a decrease in blood } \\
\text { pressure in the SEFT } \\
\text { intervention group, namely } \\
\text { systole } 23.32 \mathrm{mmHg} \text { and } \\
\text { diastole } 14.03 \mathrm{mmHg} \text {. }\end{array}$ \\
\hline
\end{tabular}

Emotional Freedom Technique (EFT) is an emotional liberation technique that aims to free negative emotions that can cause health problems. By tapping the meridian points as a link for the organs that become one unit and acting together in tune with every incoming stimulus to defend the body, so that if disease enters the meridian, the meridian becomes the pathway to other organs [8].

In the EFT method there is a homeostatic conception which is an important concept in maintaining health or body equilibrium, with this homeostatic body automatically under the command of the brain, all external and internal body disturbances are responded to quickly. Homeostasis in the blood automatically encourages the kidneys to release renin or the brain 
encourages the release of anti-diuretic hormone (ADH) so that at a certain time the body can return to normal. Homeostasis is not only to overcome problems that arise but also to anticipate when there is an imbalance in the body [8].

The imbalance in the body, according to Craig, is due to the negative emotions that exist in him which can disrupt the body's energy system so that it disturbs the balance or homeostasis of the body. If the forebrain, limbig, hindbrain and both sides of the left and right brain have enough energy, then a person can balance the mind and can give the right response to face the challenges of daily life but if the energy balance is disturbed it can give the wrong response, even used to make the whole body become negative, stress or other emotional symptoms.

Negative responses caused by stress and other emotional symptoms in the study [9] said that EFT can reduce anxiety, pain, stress disorders, increase happiness, increase in immunoglobulin A, improve circulatory system, decrease blood pressure and decrease cortisol levels after EFT therapy. Where at the time of tapping at the meridian points, the hypothalamus pituitary adrenal (HPA) stimulation occurs to stimulate the parasympathetic nerve which causes a relaxing effect, with relaxation it can reduce anxiety tension, reduce cortisol levels, reduce heart rate, widen the diameter of blood vessels so that it can lower blood pressure. The function of cortisol is to regulate arteriolar tone and maintain blood pressure (stimulate the secretion of angiotensin II), increase glomerular filtration (GRF), water secretion, potassium secretion, sodium retention and suppress calcium uptake in the renal tubules. This research is in line with research [10] where after doing EFT therapy can significantly reduce anxiety levels and can reduce cortisol levels.

Research [11] on presence of stress induction can increase the release of cortisol levels which have a negative effect, where stress can last for 65 to 100 minutes after receiving stress, this study proves that an increase in cortisol levels due to stress impulses, stress involves activation of the endocrine stress response system in the hypothalamus. Stress is a condition caused by a stressor. Stress can also be interpreted as a homeostatic disturbance that causes changes in physiological balance resulting from physical and psychological stimuli. As an adaptive response to stress, changes in serum levels of various hormones including corticotrophin releasing hormone $(\mathrm{CRH})$, cortisol and epinephrine occur. Cortisol is the main hormone that regulates certain levels of inflammation and a marker of immunity and neo transmitters. High levels of cortisol correlate with stress, immune function, inflammation and increased heart rate [12].

Cortisol levels increase as the body's response to emotional stimulation, anxiety and stress, according to the research results [13] where by using the Spiritual Emotional Freedom Technique (SEFT) method is effective in reducing cortisol levels in primigravida mothers. so that both the EFT and SEFT methods are equally effective in efforts to reduce stress, reduce anxiety, lower blood pressure to prevent hypertension in preeclamptic patients (SEFT is part of EFT) and also on research [14] EFT method is effective in reducing pain and reducing anxiety, where tapping the meridian points will respond to the peripheral nerve network to involve the central nerve. When tapping the nerves, it sends stimulating neo transmitters to move through the spinal cord to the hypothalamus and pituitary, resulting in an effect on the secretion of B-endorphins, encephalins and serotonin which act as pain inhibitors. The secretion of this neurotransmitter also plays a role in the improvement of psychological diseases such as mood disorders, depression, and anxiety [15].

EFT and SEFT are believed to be effective in lowering blood pressure in hypertensive patients, where the tapping technique is performed to provide a relaxing effect where the relaxation has an impact on decreasing sympathetic nerve activation, causing a decrease in 
breath frequency, blood pressure and heart rate. This relaxed condition results in the production of catecholamines, thereby reducing stress and ultimately lowering blood pressure, this is in line with the research [16] EFT therapy is effective in lowering blood pressure in the elderly. Research conducted [17] shows that the SEFT method is effective in lowering blood pressure because of the relaxation that is quite effective in controlling stress in a person, so that the factors that cause hypertension can be inhibited and high blood pressure will gradually change towards normal.

Research conducted [18], SEFT method is effective in lowering blood pressure in elderly with hypertension, this study is in line with the research conducted [19] and research conducted [20] where with the SEFT method which is carried out at least once a day is able to reduce blood pressure in patients with hypertension.

\section{Conclusion}

So, it can be concluded that the EFT and SEFT methods are very beneficial in improving health, where the EFT and SEFT methods can provide a relaxing effect in order to reduce cortisol levels, reduce anxiety and emotions. By tapping, it can reduce the level of cortisol, one of the activation hormones that is influenced by cortisol, namely epinephrine, so there is no increase in arteriolar vasoconstriction to prevent hypertension in preeclampsia patients. By implementing emotional freedom techniques so that the EFT and SEFT methods are expected to be able to deal with emotional problems as a trigger for the onset of a disease both physically and psychologically

\section{References}

[1] ACOG. Clinical Management Guidelines for Obstetrician - Gynecologists. Obstet Gynecol 2019;133(76):168-186.

[2] World Health Organization. Kematian Maternal dan Neonatal di Indonesia. Rakerkernas 2019 2019;1-47.

[3] Noerpramana N. Praktis Klinis Obstetri Ginekologi. Yogyakarta: Cakrawala Media; 2013.

[4] Kementrian Kesehatan RI. Informasi Kesehatan Indonesia 2019. kementrian Kesehat RI 2019;8(9):1-58.

[5] Wafda et al. Asuhan Kebidanan Kasus Kompleks Maternal \& Neonatal. Yogyakarta: Pustaka Baru Press; 2019.

[6] Ifeagwazi CM, Egberi HE, Chukwuorji JC. Emotional reactivity and blood pressure elevations: Anxiety as a mediator. Psychol Heal Med 2018;23(5):585-592.

[7] Neuman WL. Sosial Research Methods. Qualitative and Quantitative Approaches. Boston: Pearson; 2011.

[8] Akmal Sutja D. Emotional Freedom Technique Cara Cepat Mengatasi Gangguan Emosional. kesatu. Bandung: Alfabeta; 2018.

[9] Bach D, Groesbeck G, Stapleton P, Sims R, Blickheuser K, Church D. Clinical EFT (Emotional Freedom Techniques) Improves Multiple Physiological Markers of Health. J Evidence-Based Integr Med 2019;24:1-12.

[10] Mardjan M, Prabandari YS, Hakimi M, Marchira CR. Emotional Freedom Techniques for Reducing Anxiety and Cortisol Level in Pregnant Adolescent Primiparous. Unnes J Public Heal 2018;7(1):16. 
[11] Admon R, Treadway MT, Valeri L, Mehta M, Douglas S, Pizzagalli DA. Distinct trajectories of cortisol response to prolonged acute stress are linked to affective responses and hippocampal gray matter volume in healthy females. J Neurosci 2017;37(33):7994-8002.

[12] Sherwood L. Fisiologi Manusia Dari Sel ke Sistem. 8th ed. Jakarta: EGC; 2014.

[13] Yuniarti, Suwondo A, Runjati. Pengaruh Terapi Spiritual Emotional Freedom Technique (SEFT) terhadap Kadar Kortisol dan Imunoglobulin E: (Studi Kecemasan pada Ibu Hamil di Bidan Praktek Mandiri Kota Semarang). J Ilmu Keperawatan Dan Kebidanan 2016;02:201-9.

[14] Latifah L, Setiawati N, Rismawati I. Are there any effects of tapping therapy in reducing anxiety and labor pain in the latent phase? Ann Trop Med Public Heal 2019;22(11).

[15] Purba J. Mekanisme kerja akupuntur dan aplikasi klinik. jakarta: Departemen Neurologi FKUI/RSCM; 2010.

[16] Isworo A, Anam A, Indrawati N. Pengaruh Terapi Emotional Freedom Technique (EFT) dalam Menurunkan Tekanan Darah pada Lansia Hipertensi. Gaster 2019;17(2):154.

[17] Hidayatulloh B, Lismayanti L. Terapi Spiritual Emotional Freedom Technique ( SEFT ) Menurunkan Tekanan Darah Pasien Hipertensi di UPTD Puskesmas Cilembang Kota Tasikmalaya PENDAHULUAN Hipertensi adalah suatu keadaan ketika tekanan darah di pembuluh darah meningkat secara kronis . Hal . 2018;2(1):4-5.

[18] Ros Endah Happy Patriyani DS. Menurunkan Tekanan Darah pada Lansia dengan Hipertensi melalui SEFT Ros Endah Happy Patriyani 1*, Dwi Sulistyowati 2 1,2. 2020;9-17.

[19] Permatasari AS, Sri R, Pujiastuti E, Kristatnto D. Spiritual Emotional Freedom Technique ( SEFT ) Intervention on Blood Pressure among Pregnancy with Hypertension. Int J Nurs Heal Serv 2020;3(3):402-10.

[20] Huda S, Alvita GW. Pengaruh Terapi Seft (Spiritual Emotional Freedom Technique) Terhadap Penurunan Tekanan Darah Pada Penderita Hipertensi Di Wilahah Puskesmas Tahunan. J Keperawatan dan Kesehat Masy Cendekia Utama 2018;7(2):114. 